OPEN ACCESS

Edited by:

Eleanor Riley,

University of Edinburgh,

United Kingdom

Reviewed by:

Jayne Hope,

University of Edinburgh,

United Kingdom

John Anthony Hammond,

Pirbright Institute (BBSRC),

United Kingdom

Preben Boysen,

Norwegian University of Life

Sciences, Norway

*Correspondence:

Philip John Griebel

philip.griebe/@usask.ca

Specialty section: This article was submitted to NK and Innate Lymphoid Cell Biology,

a section of the journal

Frontiers in Immunology

Received: 03 August 2017 Accepted: 09 October 2017

Published: 23 October 2017

Citation:

Osman RA and Griebel PJ (2017) CD335 (NKp46)+ T-Cell Recruitment

to the Bovine Upper Respiratory

Tract during a Primary Bovine Herpesvirus-1 Infection.

Front. Immunol. 8:1393.

doi: 10.3389/fimmu.2017.01393

\section{CD335 (NKp46)+ T-Cell Recruitment to the Bovine Upper Respiratory Tract during a Primary Bovine Herpesvirus-1 Infection}

\author{
Rahwa A. Osman ${ }^{1,2}$ and Philip John Griebel1,2* \\ ${ }^{1}$ Vaccinology and Immunotherapeutics Program, School of Public Health, University of Saskatchewan, Saskatoon, SK, \\ Canada, ${ }^{2}$ Vaccine and Infectious Disease Organization-International Vaccine Centre (VIDO-Intervac), University of \\ Saskatchewan, Saskatoon, SK, Canada
}

Bovine natural killer (NK) cells were originally defined by the NK activation receptor CD335 [natural killer cell p46-related protein (NKp46)], but following the discovery of NKp46 expression on human T-cells, the definition of conventional bovine NK cells was modified

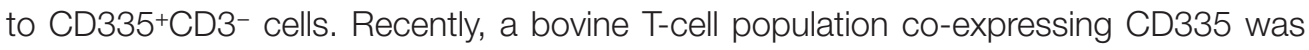
identified and these non-conventional T-cells were shown to produce interferon (IFN)- $\gamma$ and share functional properties with both conventional NK cells and T-cells. It is not known, however, if CD335+ bovine T-cells are recruited to mucosal surfaces and what chemokines play a role in recruiting this unique T-cell subpopulation. In this study, bovine herpesvirus-1 (BHV-1), which is closely related to herpes simplex virus-1, was used to investigate bovine lymphocyte cell populations recruited to the upper respiratory tract following a primary respiratory infection. Immunohistochemical staining with individual monoclonal antibodies revealed significant $(P<0.05)$ recruitment of $\mathrm{CD} 335^{+}, \mathrm{CD}^{+}$, and $\mathrm{CD} 8^{+}$lymphocyte populations to the nasal turbinates on day 5 following primary BHV-1 infection. Dual-color immunofluorescence revealed that cells recruited to nasal turbinates were primarily T-cells that co-expressed both CD335 and CD8. This non-conventional T-cell population represented $77.5 \%$ of $\mathrm{CD} 355^{+}$cells and $89.5 \%$ of $\mathrm{CD} 8^{+}$cells recruited to nasal turbinates on day 5 post-BHV-1 infection. However, due to diffuse IFN- $\gamma$ staining of nasal turbinate tissue, it was not possible to directly link increased IFN- $\gamma$ production following BHV-1 infection with the recruitment of non-conventional T-cells. Transcriptional analysis revealed CCL4, CCL5, and CXCL9 gene expression was significantly $(P<0.05)$ upregulated in nasal turbinate tissue following BHV-1 infection. Therefore, no single chemokine was associated with recruitment of non-conventional T-cells. In conclusion, the specific recruitment of CD335+ and CD8+ non-conventional T-cells to viral-infected tissue suggests that these cells may play an important role in either the clearance of a primary BHV-1 infection or regulating host responses during viral infection. The early recruitment of non-conventional T-cells following a primary viral infection may enable the host to recognize viral-infected cells through NKp46 while retaining the possibility of establishing T-cell immune memory.

Keywords: bovine herpesvirus-1, chemokines, interferon- $\gamma$, lymphocyte recruitment, non-conventional T-cells 


\section{INTRODUCTION}

Bovine herpesvirus-1 (BHV-1), a member of Alphaherpesvirinae subfamily, is an important pathogen contributing to bovine respiratory disease complex in young calves. BHV-1 causes a rhinotracheitis in the upper respiratory tract (URT) (1) and, similar to other alphaherpesviruses in humans, pigs and horses, causes a lytic infection of mucosal epithelial cells (2) followed by a latent infection in the peripheral nervous system. The primary sites of BHV-1 infection in the URT include the nasal turbinates, pharyngeal tonsils, and trachea (3). Previous studies suggested that interferon (IFN) does not play a major role in the clearance of a primary BHV-1 infection (4) but cytotoxic cell-mediated immune responses mediated by macrophages, neutrophils, natural killer (NK) cells, and cytotoxic T-lymphocytes (CTLs) may contribute to viral clearance (5-7).

Natural killer cells are non-antigen-specific innate lymphocytes that respond rapidly to both infectious and non-infectious challenges. NK cells express both activation and inhibitory receptors. These heterologous receptors include killer-cell immunoglobulin-like receptors and natural cytotoxicity receptors (NCRs) such as natural killer cell p46-related protein (NKp46) [natural cytotoxicity triggering receptor 1 (NCR1) or CD335], NKp30, and NKp44 (8). CD335 is the only NK receptor currently characterized for bovine NK cells (9) and is an activating receptor on NK cells, which binds ligands and initiates signaling that activates cytotoxic responses. This was demonstrated by activation of human NK cell cytotoxicity following NKp46-binding of hemaglutinin of influenza viruses (10). This activation signal results in the release of cytotoxic granules, which kill target cells through the combined action of perforin and granzyme (11).

CD335 was originally described as a bovine NK cell-specific receptor (9) but a small subpopulation of bovine T-cells have also been identified that co-express CD335 $(9,12-14)$. CD $335^{+} \mathrm{CD}^{-}$ cells are now defined as classical or conventional NK cells and lymphocytes that co-express $\mathrm{CD} 3$ and $\mathrm{CD}_{3} 35^{+}$are described as non-conventional T-cells. Multiple non-conventional T-cells have been reported in several mammalian species, including humans (15), mice (16), pigs (13), and bovine (12). The discovery of reprogrammed human CTLs that co-express CD3 and NKp46 in celiac disease (15) highlighted the existence of T-cells acquiring NCRs previously associated with NK cells. Other non-conventional T-cells include natural killer T (NKT) cells and mucosal-associated invariant T (MAIT) cells that co-express CD3 and NCRs.

Natural killer T-cells were first discovered in mice (17) and characterized as a T-cell subpopulation expressing NK1.1 and $\alpha \beta$ T-cell receptors $(17,18)$. In species that do not express NK1.1, the term NKT has been used to refer to T-cells which co-express NK cell receptors (19). NKT cells studied in humans and mice were shown to express an invariant T-cell receptor (TCR) and were termed invariant (i)NKT cells. This population recognized a limited repertoire of ligands relative to the extensive repertoire of conventional MHC-restricted T-cells. NKT cells also recognize lipid ligands complexed with the non-MHC surface molecule, CD1d, and were also referred to as "CD1d-restricted" T-cells (20). CD1d is absent in cattle (21) but bovine T-cells co-expressing CD335 do recognize lipid ligands by a CD1d-independent mechanism (22).

Mucosal-associated invariant T-cells were first observed in human blood by Porcelli et al. (23) as unconventional $\alpha \beta$ T-cells with invariant TCR $\alpha$ chain and semi-invariant TCR repertoire. These non-conventional T-cells have since been identified in mice and found to be enriched at mucosal surfaces (24). MAIT cells recognize antigens in the context of a non-classical-MHC molecule, MR1 (24). Recent studies have shown that MAIT cells have antimicrobial functions (25) and recognize vitamin B metabolite ligands (26). MAIT cells have not been characterized in cattle but bovine non-conventional T-cells that co-express CD335 have been shown to have a cytotoxic effector function with parasiteinfected cells and secrete IFN- $\gamma(12)$. No information is available, however, regarding the role of these cells in controlling infections at mucosal surfaces.

Homing of innate and adaptive lymphocytes to sites of viral infection is crucial for effective cell-mediated immune responses and clearance of viral-infected cells. Different non-conventional T-cell subsets home to specific tissues based on their expression of chemokine receptors and intrinsic tissue responses to pathogens or other danger signals (27). Murine iNKT cells express CCR7, CXCR3, CXCR6, CCR4, and CCR6 chemokine receptors (28), of which CCR4 (29) is important for pulmonary localization. CXCR6, CCR1, and CCR6 are expressed by human NKT cells (30) but the chemokine receptors expressed by bovine non-conventional T-cells and the chemokines involved in their recruitment to specific tissues has yet to be determined. Previous studies demonstrated that non-MHC-restricted lymphocytes were recruited to the lungs of calves following BHV-1 infection (7) but it was not determined whether these cells were conventional NK cells or non-conventional T-cells. It is not known if non-conventional T-cells may be recruited to bovine mucosal surfaces since previous studies of bovine non-conventional T-cells were limited to cells isolated from blood $(12,21,22)$.

In this study, we demonstrate that non-conventional T-cells co-expressing CD335 and CD8 are recruited to the bovine URT following an experimental BHV-1 infection and these non-conventional T-cells are the major effector cell population recruited within 5 days post-infection (pi). Our analysis of chemokine gene expression at the site of viral infection also identified multiple chemokines that may be involved in the highly specific recruitment of this non-conventional T-cell population. Thus, CD $335^{+}$ and $\mathrm{CD}^{+}$bovine non-conventional T-cells appear to be the primary effector cell population involved in the early immune response to a BHV-1 URT infection.

\section{MATERIALS AND METHODS}

\section{Animals}

Female and castrated male, 5- to 6-month-old, crossbred (Angus $\mathrm{X}$ Hereford) calves $(n=30)$ were purchased from a single commercial herd. Calves were identified as seronegative for BHV-1 by screening with a recombinant, truncated glycoprotein $\mathrm{D}$ antibody capture ELISA (31). Calves were weaned, transported to the research facility, and adapted for 2 weeks to a diet of free 
choice hay and $0.5 \mathrm{~kg}$ oats/day. During the adaptation period, calves were housed as a single group and there was no contact with other cattle. The average weight of calves was $232 \mathrm{~kg}$ (range $=174$ and $242 \mathrm{~kg}$ ), and the animals were housed in a single pen throughout the study. All experimental procedures were conducted according to the Guide to the Care and Use of Experimental Animals, provided by the Canadian Council on Animal Care and the experimental protocols were approved by the University of Saskatchewan Animal Care Committee (Protocol \#19940211 and 19940218). The animals used for tissue collection were the same animals used to analyze virus shedding, IFN gene expression, and the expression of IFN-stimulated genes in a previous study (4). In our previous study, we demonstrated that all infected animals shed greater than $10^{5}$ infectious virus particles/ml of nasal secretion at the time tissues were collected between days 3 and 7 pi (4). BHV-1 infection of nasal turbinate mucosal epithelium was also confirmed by immunohistochemical (IHC) staining (4).

\section{Experimental Infection and Sample Collection}

Six (6) of the 30 calves served as uninfected controls and tissue samples were collected from the control animals immediately prior to challenging the remaining 24 calves with BHV-1. This ensured there was no potential exposure of control calves to $\mathrm{BHV}-1$. The 24 infected calves were aerosol challenged with BHV-1 isolate $108\left(5 \times 10^{7} \mathrm{pfu} / \mathrm{animal}\right)$ on experimental day 0 as previously described (32). A clinical veterinarian, blinded to treatment group, examined calves daily and recorded body weight and temperature. For tissue collection, cohorts of six calves were randomly selected and euthanized with an intravenous injection of Euthanyl (240 mg/ml; Bimeda-MTC, Canada) on days 3, 5 7, and 10 pi. Tissue samples were collected within 15-20 min after euthanasia, and three replicate samples were immediately placed in RNAlater or $10 \%$ buffered formalin. Tissue samples from nasal turbinates were collected $10-12 \mathrm{~cm}$ from the external nares of all calves (Figure S1 in Supplementary Material). A 4-5 $\mathrm{mm}^{2}$ piece of nasal turbinate was placed on the surface of a $4-5 \mathrm{~mm}^{2}$ and 1-mm thick slice of fresh liver tissue with the epithelial surface of the turbinate supported by the liver. This protected the mucosal epithelium from damage during cryosectioning. Tissue blocks were snap-frozen in liquid nitrogen and stored at $-80^{\circ} \mathrm{C}$ until tissues were used for cryosectioning and IHC staining. Formalin-fixed tissues were used for histology and IHC detection of BHV-1 proteins. Tissues fixed with RNAlater were stored at $-80^{\circ} \mathrm{C}$ until RNA was extracted for qRT-PCR analysis of bovine chemokine gene expression.

\section{Monoclonal Antibodies (mAbs)}

The mAbs used for IHC and immunofluorescence (IF) and relevant isotype controls are listed in Table 1, which provides details on $\mathrm{mAb}$ specificity and the concentration of each $\mathrm{mAb}$ used for staining.

\section{Lymphocyte Phenotyping with Immunohistochemistry}

Three 4-5 $\mathrm{mm}^{2}$ nasal turbinate tissue samples were collected from each animal and tissue blocks were randomly selected for cryosectioning. Tissue blocks were sectioned at $-20^{\circ} \mathrm{C}$, and 5- $\mu \mathrm{m}$ tissue sections were cut using a cryostat (DAMON/ IEC Division, Microtome 3398) and mounted on Superfrost Plus slides (Fisherbrand\#12550215, ON, Canada). Serial tissue sections were selected for IHC staining on the basis of optimum tissue morphology. Tissue sections were fixed in chilled $100 \%$ acetone for $8 \mathrm{~min}$ and air-dried for $20 \mathrm{~min}$ prior to storage at $4^{\circ} \mathrm{C}$. Indirect-immunolabelling was performed as described previously (33) to visualize the location and distribution of IFN$\alpha$ and IFN- $\gamma$ in tissue sections and to perform morphometric analyses of the frequency of $\mathrm{CD}_{3} 35^{+}, \mathrm{CD}^{+}, \mathrm{CD}^{+}$, and $\mathrm{CD} 4^{+}$ cells in nasal turbinates before infection (day 0 ) and on day 3 , 5,7 , and 10 post-BHV-1 infection. Biotin-conjugated goat-antimouse IgG (Vector Laboratories, Burlingame, CA, USA \#BA9200) and the Vectastain Elite Avidin-Biotin complex Kit (Vector Laboratories, Burlingame, CA, USA \#PK4000) were used to visualize bound $\mathrm{mAbs}$. $\mathrm{BHV}-1$ infection occurs primarily within mucosal epithelial cells of the nasal turbinate (4). Thus, boundaries set for morphometric analysis of individual lymphocyte populations included the mucosal epithelium and the underlying lamina propria region. Five contiguous microscopic fields (total area $=0.196 \mathrm{~mm}^{2}$ ) were analyzed within each tissue section, and cells with visible staining were manually counted using an Olympus CX31 microscope (Olympus, Center Valley, PA, USA) with a $40 \times$ objective. The first field counted was located at the upper left corner of the cryosection and four contiguous fields were then counted. The top margin of each field was defined by the external surface of the mucosal epithelium and included the

TABLE 1 | Monoclonal antibodies used for Immunohistochemistry and immunofluorescence.

\begin{tabular}{|c|c|c|c|c|c|c|}
\hline CD & Target molecule & Target population & Isotype & mAb clone & Conc. & Source \\
\hline CD4 & $\mathrm{CD} 4$ & $\mathrm{~T}_{\mathrm{H}}$ cells, $\mathrm{DC}$ & $\lg \mathrm{G}_{1}$ & CACT138A & $10 \mu \mathrm{g} / \mathrm{ml}$ & VMRD \\
\hline CD8 & $\mathrm{CD} 8 \alpha$ & CTLs, DC & $\lg G 1$ & САСТ8ОС & $5 \mu \mathrm{g} / \mathrm{ml}$ & VMRD \\
\hline $\operatorname{slg} A$ & Surface $\lg A$ & IgA plasma cells & $\lg G_{1}$ & BIG312D3 & $125 \mathrm{ng} / \mathrm{ml}$ & VMRD \\
\hline Interferon (IFN)- $\alpha$ & $\mathrm{IFN}-\alpha$ & IFN- $\alpha$ & $\lg \mathrm{G}_{1}$ & Ascites & $1: 400$ dilution & VIDO \\
\hline $\mathrm{IFN}-\gamma$ & $\mathrm{IFN}-\gamma$ & $\mathrm{IFN}-\gamma$ & $\lg G_{1}$ & 7B6 & $2 \mu \mathrm{g} / \mathrm{ml}$ & LSBio \\
\hline
\end{tabular}

CD, cluster of differentiation; TCR, T-cell receptor; TH cells, T-helper cells; DC, dendritic cells; CTLs, cytotoxic T-Iymphocytes; NCR1, natural cytotoxicity triggering receptor 1; NKp46, natural killer cell p46-related protein. 
underlying lamina propria. An Olympus BX51 microscope and DP70 digital camera system (Olympus, Center Valley, PA, USA) were used to capture images of IHC-stained cryosections.

\section{Immunofluorescence}

Dual-color staining of tissue sections was performed using fluorochrome-conjugated mAbs that reacted with bovine CD3, CD8, and CD335. The mAbs (Table 1) were conjugated with fluorochromes using Molecular Probes ${ }^{\circledR}$ Antibody Labeling Kit (Thermofisher Scientific, Carlsbad, CA, USA), following the manufacturer's instructions. The anti-bovine CD3 mAb was conjugated with Alexa Fluor ${ }^{\circledR}$ 594. The anti-bovine CD8 mAb was conjugated with Alexa Fluor ${ }^{\circledR} 488$ and Alexa Fluor ${ }^{\circledR}$ 594 , so it could be used in appropriate combinations with the fluorochrome-conjugated CD3 and CD335 mAbs. IgG1 isotype control mAb (Table 1) was conjugated with Alexa Fluor ${ }^{\circledR} 594$ to be used for confirmation of staining specificity of the three other fluorochrome-conjugated antibodies. Direct fluorochrome labeling was necessary since the three mAbs are all IgG1 isotype (Table 1) and $\mathrm{mAb}$ reactivity after fluorochrome conjugation was confirmed by flow cytometric analysis of labeled blood mononuclear cells. Serial nasal turbinate cryosections were cut and fixed as described previously and stored at $4^{\circ} \mathrm{C}$ overnight. Acetone-fixed sections were brought to room temperature, air-dried for $30 \mathrm{~min}$, and then rehydrated with phosphate buffered saline (PBS). The PBS solution was changed three times at $5 \mathrm{~min}$ intervals before slides were blocked by incubating with $10 \%$ normal goal serum for $3 \mathrm{~h}$, followed by a $5 \mathrm{~min}$ wash with PBS. Tissue sections were then flooded with $200 \mu \mathrm{l}$ of PBS containing 5\% normal goat serum and one of the following combinations of fluorochrome-conjugated mAbs: CD3 and CD335; CD335 and CD8; or CD3 and CD8. Cryosections were incubated in the dark at room temperature for $2.5 \mathrm{~h}$ before washing twice for $5 \mathrm{~min}$ with PBS that was mixed with a magnetic stirrer. Tissue sections were counterstained by flooding with $200 \mu \mathrm{l} \mathrm{4}$,6-diamidino-2-phenylindole $(1 \mu \mathrm{g} / \mathrm{ml}$ methanol) (Life Technologies, Camarillo, CA, USA) for $10 \mathrm{~min}$ at room temperature to visualize cell nuclei and then washed for 5 min with PBS. Tissue sections were cover slipped with Cytoseal 60 mounting media (Thermofisher Scientific, Carlsbad, CA, USA) and stored overnight at $4^{\circ} \mathrm{C}$ before fluorescent imaging was completed. Confocal images were generated using a Leica TCS SP8 scanning confocal microscope (Leica Microsystems, Wetzlar, Germany), equipped with a $63 \times$ oil immersion objective and utilizing the $405 \mathrm{~nm}$ (UV) and $561 \mathrm{~nm}$ laser lines. Confocal images from a minimum of 15 microscopic fields were captured per sample, and a minimum of $100 \mathrm{CD} 335^{+}, \mathrm{CD}^{+}$, and $\mathrm{CD} 8^{+}$cells were counted per tissue section. Tissue sections were analyzed for nasal turbinate samples collected from three animals on day 5 pi to determine the frequency of $\mathrm{CD} 335^{+} \mathrm{CD} 3^{+}, \mathrm{CD}_{3} 35^{+} \mathrm{CD} 8^{+}$, and $\mathrm{CD}^{+}{ }^{+} \mathrm{CD} 8{ }^{+}$cells.

\section{RNA Extraction}

RNAlater $^{\circledR}$ fixed nasal turbinate samples were homogenized as previously described (34) and total RNA was extracted using the RNeasy mini Kit (Qiagen Inc., Ontario, CA, USA) following the manufacturer's protocol. RNA quality and total RNA were determined using the Agilent 2100 Bioanalyzer (Agilent Technologies,
Santa Clara, CA, USA). Samples with an RNA integrity number of eight or higher were used to prepare cDNA.

\section{cDNA Synthesis}

Total RNA $(1 \mu \mathrm{g})$ was reverse-transcribed using qScript ${ }^{\mathrm{TM}} \mathrm{cDNA}$ SuperMix (Quanta Biosciences ${ }^{\mathrm{TM}}$ Beverly, MA, USA), following the manufacturer's protocol. cDNA samples were diluted in DNAse/RNAse free water for use as template in qRT-PCR reactions.

\section{qRT-PCR Primer Design and Validation}

Primer pairs for chemokine transcripts (Table 2) were designed using Clone Manager 9.0 program (Sci-Ed Software). Primer specificity for individual chemokine genes was confirmed through generation of a single peak in the melting curve and detecting a single amplicon following gel electrophoresis of PCR products. PCR products were also cloned in the PCR 2.1 vector using the TA cloning kit (Life Technologies, Camarillo, CA, USA). Cloned products were sequenced with a CEQ 200XL DNA Analysis system (Beckman Coulter) to confirm product identity and size. Primer amplification efficiency (Table 2) was determined using standard curves as described previously (35).

TABLE 2 | Primers for amplification of bovine genes.

\begin{tabular}{|c|c|c|c|c|}
\hline \multicolumn{2}{|l|}{ Gene } & \multirow{2}{*}{$\begin{array}{l}\text { Primer sequence }^{\mathbf{a}} \\
\text { TCGCTGCAACATGAAGGTCT }\end{array}$} & \multirow{2}{*}{$\frac{\text { Size }^{\text {b }}}{119}$} & \multirow{2}{*}{$\begin{array}{c}\text { Efficiency } \\
2.02\end{array}$} \\
\hline CCL2 & FWD & & & \\
\hline$(M C P-1)$ & $\mathrm{RV}$ & TATAGCAGCAGGCGACTTGG & & \\
\hline CCL3 & FWD & CGGCAGCTITCTCGCAAAAT & 166 & 1.98 \\
\hline$(M I P-1 \alpha)$ & RV & СCTCTCAGGCATTCAGCTCC & & \\
\hline CCL4 & FWD & AGCTCTGCGTGACTGTCCTG & 86 & 2.15 \\
\hline$(M I P-1 \beta)$ & $\mathrm{RV}$ & AGGGTCTGAGCCCATTGGTG & & \\
\hline CCL5 & FWD & GCTCCATGGCAGCAGTTGTC & 128 & 2.12 \\
\hline (RANTES) & $\mathrm{RV}$ & AGGTTCAAGGCGTCCTCCAC & & \\
\hline CCL19 & FWD & AGGTGCCAACGACGCTGAAG & 92 & 2.17 \\
\hline$(M I P-3 \beta)$ & $\mathrm{RV}$ & TGAGGAGCAGGTAGCGGTAG & & \\
\hline CCL20 & FWD & GACTGCTGTCTCCGATATAC & 90 & 1.98 \\
\hline$(M I P-3 \alpha)$ & $\mathrm{RV}$ & GATGTCACAGGCTTCATTGG & & \\
\hline CCL21 & FWD & TGGTCCTGAGCATCCTTGTC & 114 & 2.07 \\
\hline & $\mathrm{RV}$ & TGGCGGGAATCTTCTITCGG & & \\
\hline CXCL8 & FWD & CGCTGGACAGCAGAGCTCACA & 106 & 2.06 \\
\hline$(I L-8)$ & $\mathrm{RV}$ & TGCCAAGAGAGCAACAGCCAGC & & \\
\hline CXCL9 & FWD & AGTGGGAGAAACAGGTCAAC & 129 & 2.13 \\
\hline$(M / G)$ & RV & AAGTGGGAGCTCATGTAGTC & & \\
\hline CXCL10 & FWD & AAGGGAAAGGGTGGCTCATC & 114 & 1.98 \\
\hline$(I P-10)$ & $\mathrm{RV}$ & GGCTGGGACTTAGCACATTG & & \\
\hline CXCL-11 & FWD & AGCAGCAACAAGCATGAGTG & 100 & 2.10 \\
\hline$(I P-9)$ & $\mathrm{RV}$ & CCGTCCGCCTITGAACATAG & & \\
\hline$\beta$-Actin & FWD & CTAGGCACCAGGGCGTAATG & 116 & 2.00 \\
\hline & $\mathrm{RV}$ & CCACACGGAGCTCGTTGG & & \\
\hline GAPDH & FWD & TGGAAAGGCCATCACCATCT & 60 & 2.17 \\
\hline & $\mathrm{RV}$ & CCCACTTGATGTTGGCAG & & \\
\hline RPS9 & FWD & CCTCGACCAAGAGCTGAAG & 62 & 2.07 \\
\hline & RV & СCTCCAGACCTCACGTITGTTC & & \\
\hline
\end{tabular}

asequence of forward (FWD) and reverse (RV) primers.

${ }^{b}$ Size of amplified PCR product.

'Efficiency of product amplification. 


\section{qRT-PCR Analysis of Chemokine Gene Expression}

Gene expression data for individual samples was normalized relative to $\beta$-actin, which was confirmed to be stable over multiple time points and not affected by BHV-1 infection in nasal turbinates (data not shown). We also analyzed the expression of GAPDH and RPS9 reference genes. The expression of the three reference genes did not differ significantly when comparing samples collected at different time points following BHV-1 infection (data not shown) but $\beta$-actin transcription displayed the least variability among animals at each time point. The $\beta$-actin gene also had the lowest quantification cycle $(\mathrm{Cq})$ value when comparing among the three reference genes and was therefore selected as the best reference gene for detection of genes with high transcriptional levels. qRTPCR was performed using the PerfeCTa ${ }^{\circledR} \mathrm{SYBR}^{\circledR}$ Green FastMix for iQ (Quanta BioScience, Beverly, MA, USA). Briefly, $9 \mu \mathrm{l}$ of Perfecta SYBR green master mix $(2 \times), 3 \mu$ of the primer pair at $3.3 \mu \mathrm{M}$, and $3 \mu \mathrm{l} \mathrm{cDNA}$ template were added to a $15 \mu \mathrm{l}$ final volume. The reaction was performed in BioRad iCycler iQ PCR detection system using the following program: $1 \mathrm{cycle}$ at $95^{\circ} \mathrm{C}$ for $30 \mathrm{~s}, 45$ cycles of $95^{\circ} \mathrm{C}$ for $15 \mathrm{~s}, 60^{\circ} \mathrm{C}$ for $30 \mathrm{~s}$, and $72^{\circ} \mathrm{C}$ for $30 \mathrm{~s}$. After cycling, the temperature was increased starting from $56^{\circ} \mathrm{C}$ at a rate of $1^{\circ} \mathrm{C}$ every $10 \mathrm{~s}$ to build a melting curve (40 times). Amplification data obtained for individual genes was expressed as $\mathrm{Cq}$ and was subtracted from the Cq of the $\beta$-actin reference gene to obtain $\Delta \mathrm{Cq}(\Delta \mathrm{Cq}=\mathrm{Cq}$ gene $-\mathrm{Cq} \beta$-actin $)$.

\section{Statistical Analysis}

All statistical analyses in were performed using GraphPad software (Version 7.0a, La Jolla, CA, USA). A one-way ANOVA with Holm-Sidak's multiple comparisons test was used to compare the frequency of leukocyte subpopulations in nasal turbinates before BHV-1 infection (day 0) with each day sampled pi. A MannWhitney test was used to analyze changes in the expression level of individual chemokine genes in nasal turbinates following BHV-1 infection when compared to preinfection (day 0) levels.

\section{RESULTS}

\section{IFN Production in Nasal Turbinate Tissue}

Previous studies confirmed IFN- $\alpha$ and $-\gamma$ gene expression in nasal turbinates and the concentration of IFN in nasal secretions increased following a primary BHV-1 infection $(4,32)$. IHC staining of nasal turbinate cryosections with mAbs specific for bovine IFN- $\alpha$ and $-\gamma$ was performed to determine if the production of these cytokines could be localized to specific cells within the tissue. IHC staining revealed, however, a diffuse staining pattern with the most intense staining associated primarily with mucosal epithelial cells (Figures 1C,D). Diffuse staining was occasionally observed throughout the lamina propria but there was no consistent pattern and staining could not be localized to individual cells. Isotype-matched mAbs were used to confirm the specificity of the staining observed at the mucosal surface and in the lamina propria (data not shown). Due to the diffuse and inconsistent staining pattern observed for IFN in tissue sections, a qualitative analysis was used to determine the frequency of positive staining in nasal turbinates collected from animals before and after BHV-1 infection. Some of the nasal turbinate samples collected from uninfected animals were positive for IFN- $\alpha(3 / 6$ animals; 50\%) and IFN- $\gamma$ (4/6 animals; 60\%) (Figures 1A,B). IHC staining of day 5 tissue sections revealed more intense IFN- $\alpha$ staining of the epithelial cell layer in all animals but only $80 \%$ (5/6 animals) of the tissue samples were positively stained for IFN- $\gamma$. The staining reaction was darkest at the epithelial surface and generally less intense in the lamina propria (Figures 1C,D). Positive staining for type I IFN on day 0 (Figure 1E) may reflect environmental exposure to other pathogens or commensal microbes that maintain a basal level of innate immune activation in mucosal epithelium of the URT. IFN- $\alpha$ is a potent activator of NK cells, which may explain the concurrent expression of IFN- $\gamma$ (Figure 1F) if these innate immune cells are present in the tissue. Therefore, we investigated the types of lymphocytes present in nasal turbinates before and after BHV-1 infection.

\section{Lymphocytes Present in Nasal Turbinates following BHV-1 Infection}

We previously demonstrated that bovine IFN- $\gamma$ had limited direct antiviral activity, despite high levels of IFN- $\gamma$ production during a primary BHV-1 infection (4). Thus, the role IFN- $\gamma$ may play in clearing a primary BHV-1 respiratory infection is not known. One hypothesis is that increased IFN- $\gamma$ production may reflect increased recruitment of either NK cells or T-cells to the site of viral infection and subsequent activation of these cells by Type I IFNs. Nasal turbinates are a site of BHV-1 infection and replication, and therefore, to test this hypothesis, nasal turbinate tissue was collected from BHV-1 infected calves. IHC was used to analyze the phenotype and frequency of innate and adaptive lymphocytes present in the tissue.

Lymphoid populations present in nasal turbinates were first analyzed by staining for T-cells (CD3) and both conventional NK cells and non-conventional T-cells, which express CD335. Tissue sections were also stained for CD4 and CD8 which are markers for subsets of $\alpha / \beta \mathrm{TcR} T$-cells (36) and are also expressed on bovine NK cells and non-conventional T-cells (12). Morphometric analysis of tissue sections revealed that both T-cells $\left(\mathrm{CD}^{+}\right)$and either conventional NK cells or nonconventional T-cells $\left(\mathrm{CD} 335^{+}\right)$were present at low levels in nasal turbinates prior to BHV-1 infection (Figure 2). Cells staining for CD4 and CD8 were also present at low levels in the lamina propria prior to viral infection (Figures 2B,C and 3C; CD4 staining not shown). The number of $\mathrm{CD}_{335^{+}}, \mathrm{CD}^{+}$, and $\mathrm{CD}^{+}$cells present in the intraepithelial and lamina propria compartments increased significantly $(P<0.05)$ on day 5 pi (Figures $2 \mathrm{C}$ and 3 ) when compared to the number of cells present prior to infection (Figure 2). The increased number of cells present in nasal turbinates on day 5 then declined to preinfection levels on days 7 and 10 pi. In contrast, there was a significant $(P<0.05)$ decrease in the number of $\mathrm{CD}^{+}$cells on days 3, 7, and 10 pi (Figure 2). Cells staining for CD3 were the most abundant on day 5 pi, exceeding 100 cells per field $\left(0.196 \mathrm{~mm}^{2}\right)$ examined. The high frequency of CD3 cells on day 5 pi could not be accounted for by adding the total number of $\mathrm{CD}^{+}$and $\mathrm{CD}^{+}$cells, suggesting that other 


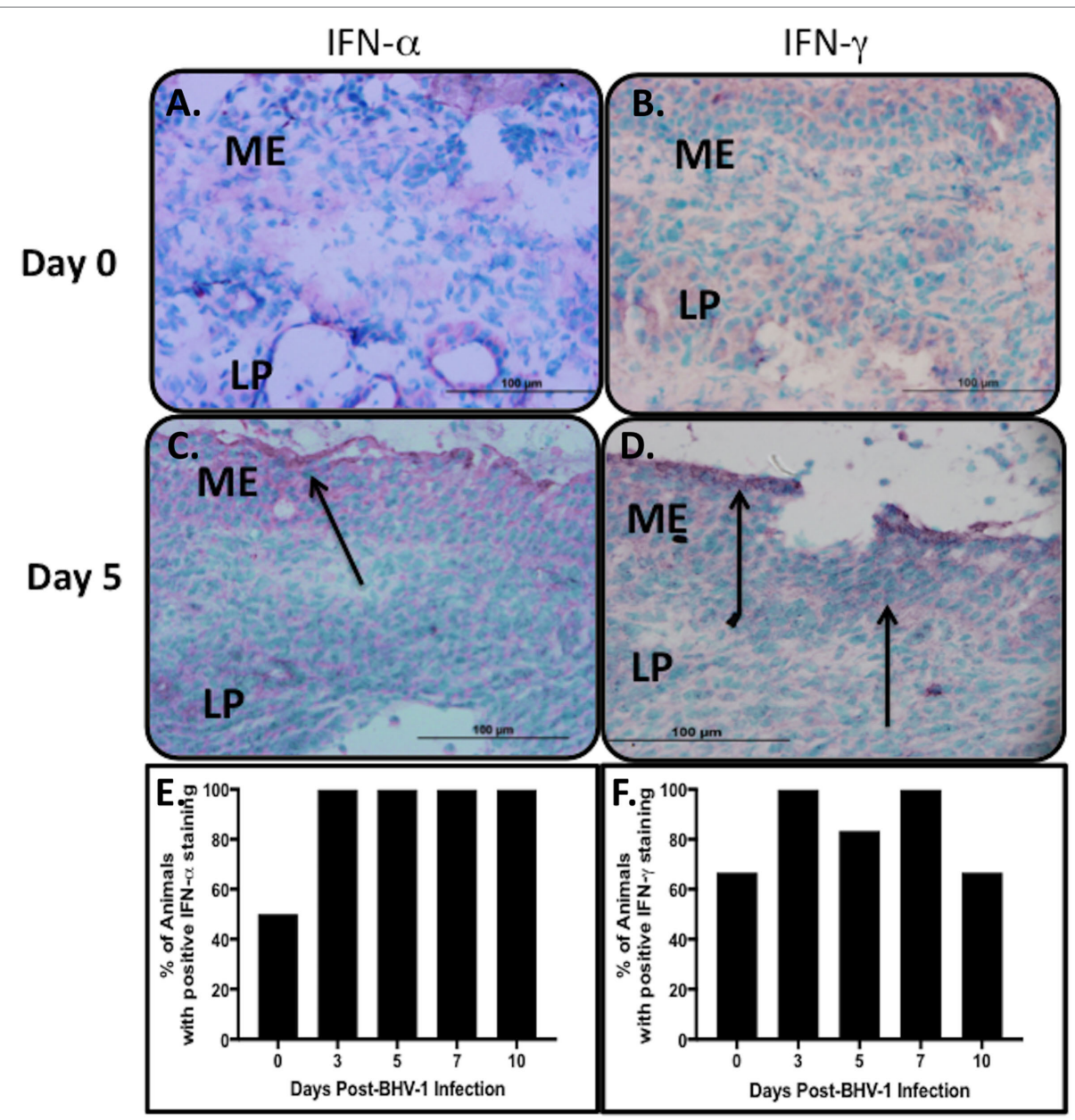

FIGURE 1 | Type 1 and 2 interferon (IFN) secretion in nasal turbinates following a primary respiratory bovine herpesvirus-1 (BHV-1) infection of naïve calves. Immunohistochemical staining of cryopreserved nasal turbinate tissues with mouse anti-bovine IFN- $\alpha$ and anti-bovine IFN- $\gamma$ monoclonal antibodies was used to visualize the location of IFN- $\alpha(\mathbf{A}, \mathbf{C})$ and IFN- $\gamma(\mathbf{B}, \mathbf{D})$ protein. Representative tissue sections are presented to demonstrate an absence of staining in the uninfected control (day 0) and the pattern of staining 5 days (day 5) after BHV-1 infection. Diffuse staining of nasal turbinate epithelial surfaces (arrows) was observed in both uninfected and BHV-1 infected calves and the percent animals $(n=6 /$ time point) with positive IFN- $\alpha(\mathbf{E})$ and IFN- $\gamma(\mathbf{F})$ staining in nasal turbinates is shown. One tissue section was stained per animal. Brown color shows positive staining.

CD3 co-expressing cell populations may be recruited to the nasal turbinates following viral infection. $\gamma \delta$ TCR T-cells are a major T-cell subpopulation present at mucosal surfaces of ruminants (37) but the mAbs evaluated for bovine $\gamma \delta T C R$ staining reacted strongly with the mucosal epithelium. This non-specific staining precluded an accurate enumeration of all known T-cell subpopulations present in nasal turbinates following BHV-1 infection. IHC staining for IgA plasma cells also revealed consistently low numbers both before and after BHV-1 infection (data not shown).

\section{Non-Conventional T-Cells Are Recruited to Nasal Turbinates following BHV-1 Infection}

The CD335 mAb binds to the NKp46 receptor on innate immune cells and is involved in the activation of NK cells and target cell lysis (9).The NKp46 receptor is, however, expressed on a variety of lymphocytes, which includes both conventional NK cells $\left(\mathrm{CD}_{3} 35^{+} \mathrm{CD}^{-}\right)$and non-conventional T-cells $\left(\mathrm{CD} 335^{+} \mathrm{CD}^{+}\right)$ that play key roles in host immune defenses and inflammation (12). Therefore, we further investigated the phenotype of the CD335 cells recruited to nasal turbinates during BHV-1 infection to determine if this might account for the large increase in $\mathrm{CD}^{+}$ cells. A double staining protocol was optimized to determine if $\mathrm{CD}_{335^{+}}$cells co-expressed CD8 (Figures 4A-C) or CD3 (Figures $4 \mathrm{D}-\mathrm{F}$ ). On average, $77.5 \%$ of $\mathrm{CD} 335^{+}$cells present in nasal turbinates on day 5 pi co-expressed CD3 while $22.5 \%$ of the $\mathrm{CD}_{3} 35^{+}$cells expressed markers typical for conventional NK cells $\left(\mathrm{CD}_{33}{ }^{+} \mathrm{CD}^{-}\right)$(Figure 4G). Further, $89.7 \%$ of $\mathrm{CD}^{-} 35^{+}$cells present on day 5 pi co-expressed CD8 (Figure 4G). Conversely, $78.5 \%$ of $\mathrm{CD}^{+}$cells present in the nasal turbinates on day $5 \mathrm{pi}$ co-expressed CD335 while $21.8 \%$ of the $\mathrm{CD}^{+}$cells co-expressed the markers of conventional T-cells $\left(\mathrm{CD}^{+} \mathrm{CD} 335^{-}\right)$(Figure 4I). Furthermore, co-staining for CD8 and CD3 revealed $86.6 \%$ of $\mathrm{CD}^{+}$cells recruited to the nasal turbinates on day 5 pi co-expressed CD3 (data not shown). Double staining for CD8 and CD3 also 

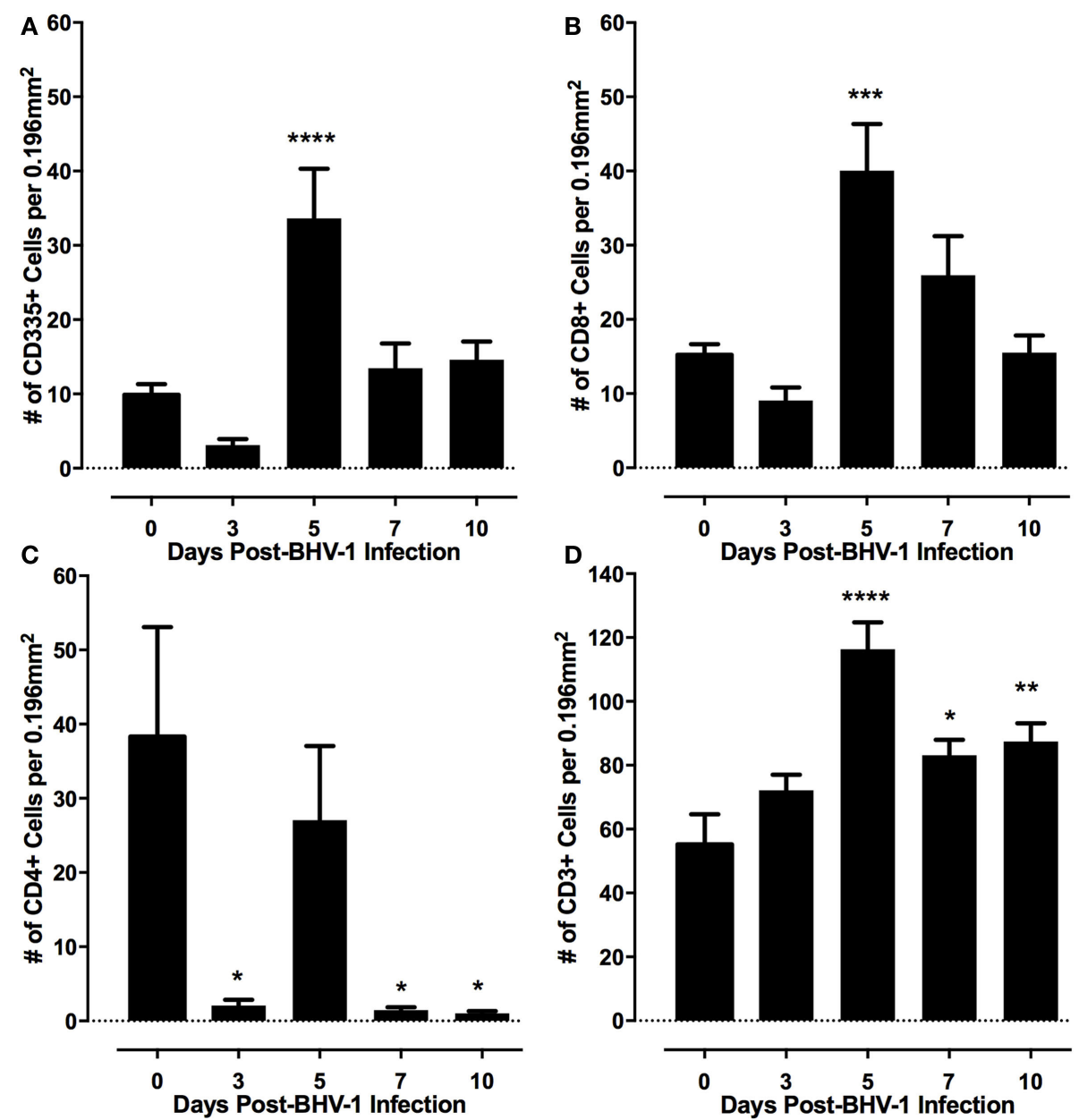

FIGURE 2 | Frequency of lymphocyte subpopulations present in nasal turbinates following a primary bovine herpesvirus-1 (BHV-1) infection. Immunohistochemical staining was performed with monoclonal antibodies to identify CD335 (A) CD8 (B) CD4 (C), and CD3 positive cells (D). Morphometric analyses were used to quantify the frequency of each cell population located within the nasal turbinate intraepithelial and submucosal compartments. Data presented are the mean and SEM for values from tissue sections analyzed from six animals/time point following BHV-1 infection. One-way ANOVA was used to compare values relative to preinfection (day 0 ) levels and significant changes in frequency of leukocytes relative to day 0 are indicated as $P<0.05\left(^{\star}\right), P \leq 0.01\left(^{\star \star}\right), P \leq 0.001\left(^{(\star \star}\right), P \leq 0.0001\left(^{(\star \star \star}\right)$.

indicated that only $73.4 \%$ of CD3 cells co-expressed CD8, which verified that other CD3-expressing cell populations were recruited to the nasal turbinates following BHV-1 infection. The specificity of the fluorescent signal observed when dual-staining cells was confirmed by the absence of detectable fluorescent signal in the mucosal epithelium and lamina propria when tissue sections were staining with flourochrome-conjugated isotype control mAbs (Figure S2 in Supplementary Material). Thus, co-expression analysis revealed that the predominant population of lymphoid cells recruited to nasal turbinates on day 5 pi were characterized by co-expression of CD335 and CD3 and the majority of these non-conventional T-cells also co-expressed CD8.

\section{Chemokine Induction following BHV-1 Infection}

Human and mouse NKT cells express many different chemokine receptors that are involved in the recruitment and localization of NKT cells at sites of inflammation (20). Chemokine receptor expression has not been characterized for bovine NKT cells but the production of IFN- $\gamma$ by human NKT has been shown to provide a positive feedback mechanism that enhances further NKT cell recruitment through induction of chemokines (38) Peak IFN- $\gamma$ production following BHV-1 infection occurs on day 5 pi and this coincides with maximum recruitment of nonconventional T-cells (Figure 2). Therefore, we designed and validated qRT-PCR primers for known bovine chemokine genes (Table 2) to investigate whether BHV-1 infection altered the expression of chemokines that may be involved in recruitment of non-conventional T-cells. Among the 10 bovine chemokine genes analyzed, transcript levels for CCL4 (Figure 5A; $P<0.05$ ), CCL5 (Figure 5B; $P<0.05$ ), and CXCL9 (Figure 5C; $P<0.01$ ) were significantly upregulated on day 7 pi. Thus, there did not appear to be a close temporal association between initial nonconventional T-cell recruitment to nasal turbinates and the onset 


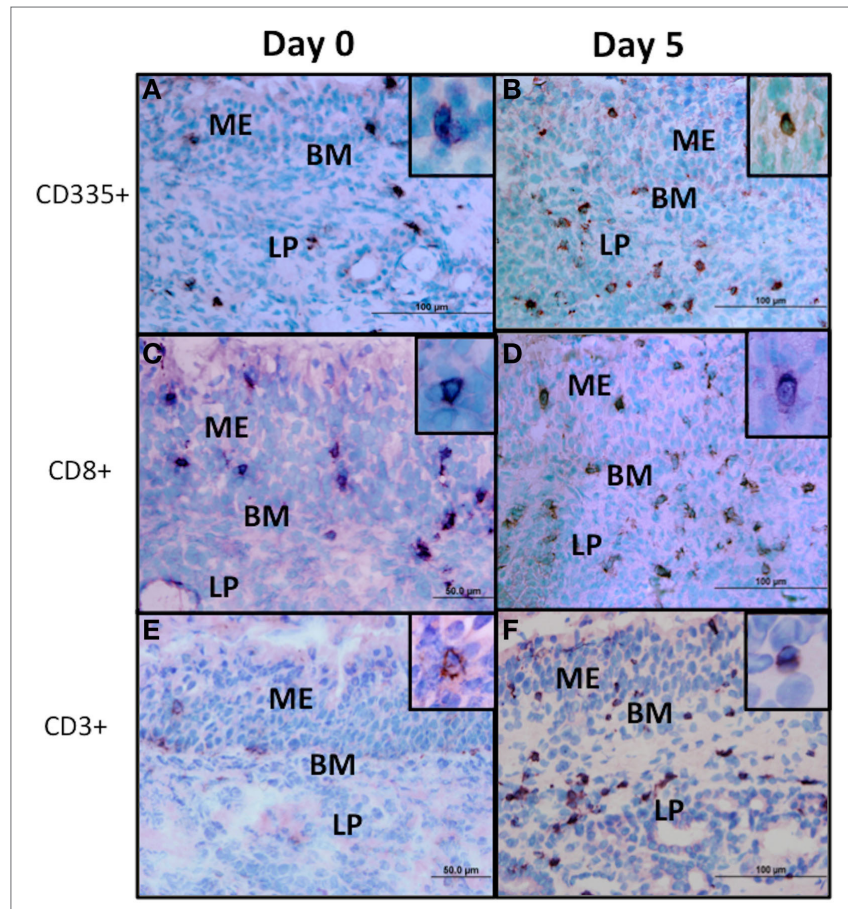

FIGURE 3 | Immunohistochemical staining of lymphocyte subpopulations present in nasal turbinates following bovine herpesvirus-1 (BHV-1) infection. Sections from cryopreserved nasal turbinate were stained with monoclonal antibodies and an immunoperoxidase conjugate to visualize the distribution of CD335 (A,B), CD8 (C,D), and CD3 (E,F) positive cells before (day 0) and 5 days (day 5 ) after $\mathrm{BH} \mathrm{V}$-1 infection. No specific cellular staining was observed when using an isotype-matched irrelevant monoclonal antibody. Positive cells stain brown and the inset in each panel shows the detail of cellular staining. Panel images were captured at $60 \times$ magnification and the inset images were captured at 100x magnification. ME, mucosal epithelium; LP, lamina propria; BM, basal membrane.

of tissue expression of chemokine genes known to be involved in NKT cell recruitment.

\section{DISCUSSION}

CD335 (NKp46, NCR1) is commonly used to identify NK cells in cattle and other mammalian species such as sheep (14) pigs (13), humans (39), and mice (16). However, non-conventional T-cell subsets co-expressing CD335 have been reported in the blood, spleen, lungs, and other tissues of both healthy and infected animals $(12,13,40)$. The current study provides the first demonstration that non-conventional T-cells co-expressing both CD335 and CD8 are the predominant lymphocyte population recruited to the URT following a primary BHV-1 infection. The frequency of $\mathrm{CD}_{3} 35^{+} \mathrm{T}$-cells in bovine blood ranges between 0.1 and $1.7 \%$ of blood mononuclear cells and $\mathrm{CD}^{+}$cells usually comprise less than $10 \%$ of all CD $335^{+}$lymphocytes in blood (12). The frequency of CD335 ${ }^{+}$T-cells recruited to the URT following a primary BHV-1 infection was $77.5 \%$ of all CD $335^{+}$lymphocytes (Figure 4H) and $78.5 \%$ of all T-cells (Figure 4I). This observation supports the conclusion that there was a highly selective recruitment of these non-conventional T-cells. Recruitment of CD $335^{+}$
T-cells to the lung of pigs was also reported following influenza infection (13), suggesting that $\mathrm{CD}_{335^{+}} \mathrm{T}$-cells may play an important role in the early control of respiratory viral infections. Non-MHC-restricted cytotoxic cells were previously reported to be recruited to the lungs of calves following a primary BHV-1 infection but the phenotype of these cells was not determined (7). Thus, further phenotypic and functional analysis of immune cells recruited during primary viral infections may reveal that non-conventional T-cells provide an important early response to infection.

The majority of non-conventional T-cells recruited to the URT also co-expressed CD8 (Figure 4G) and bovine CD335 ${ }^{+} \mathrm{CD} 8^{+}$ T-cells were shown to produce IFN- $\gamma$ when stimulated through CD3 (12). Recruitment of primarily $\mathrm{CD}^{+}$non-conventional T-cells to the URT is consistent with the previous observation that $75 \%$ of non-conventional T-cells in blood co-express CD8 (12). Maximum recruitment of non-conventional T-cells to the nasal turbinates was observed on day 5 post-BHV-1 infection which coincides with maximum IFN- $\gamma$ secretion in nasal secretions (4). The IHC staining of nasal turbinates for IFN- $\gamma$ revealed, however, a diffuse staining pattern that could not be localized to cells located in either the mucosal epithelium or submucosa (Figure 1D). Thus, it was not possible to directly link increased IFN- $\gamma$ production following BHV-1 infection with the recruitment of a large number of non-conventional T-cells. Future studies will be necessary to develop methods to isolate this unique T-cell population from tissue following viral infection for the analysis of IFN- $\gamma$ secretion or in situ analysis of IFN- $\gamma$ transcript within individual cells may determine if T-cells co-expressing CD335 are a source of IFN- $\gamma$. It would also be interesting to determine if IFN- $\alpha$ is a potent activator of IFN- $\gamma$ secretion by bovine non-conventional T-cells since peak production of both types of IFN occur on day 5 post-BHV-1 infection (4).

Innate and acquired immune responses to $\mathrm{BHV}-1$ infection have been an area of research interest for over 40 years (41), and a variety of cell-mediated cytotoxic mechanisms have been implicated as important for the control and clearance of a primary BHV-1 infection $(1,7,42)$. IFN- $\gamma$ secretion has also been frequently used as an indicator of either NK cell or T-cell activation by $\mathrm{BHV}-1$ proteins but these studies were frequently performed with lymphocytes isolated from blood (43). This is the first report that identifies effector lymphocyte populations recruited to mucosal surface of the URT following a primary BHV-1 infection. In this study, we combined IHC and IF analyses to demonstrate that $\mathrm{CD}^{+}$non-conventional $\mathrm{T}$-cells were the primary lymphocyte population recruited early during a primary $\mathrm{BHV}-1$ infection. Significant $(P<0.05)$ recruitment of this non-conventional T-cell population to the lamina propria was, however, limited to day 5 pi (Figure 2). A previous study in mice demonstrated that NK cell recruitment to lymph nodes following poxvirus infection was dependent on IFN- $\gamma$ production (44). This observation may explain the coincidence of peak non-conventional T-cell recruitment to nasal turbinates with maximum levels of IFN- $\gamma$ in nasal secretions (4). An alternative explanation may be that data showing recruitment of non-conventional T-cells was biased by sampling nasal turbinate tissues at a fixed site. BHV-1 infection in the URT of naïve calves occurs within discrete foci of mucosal 

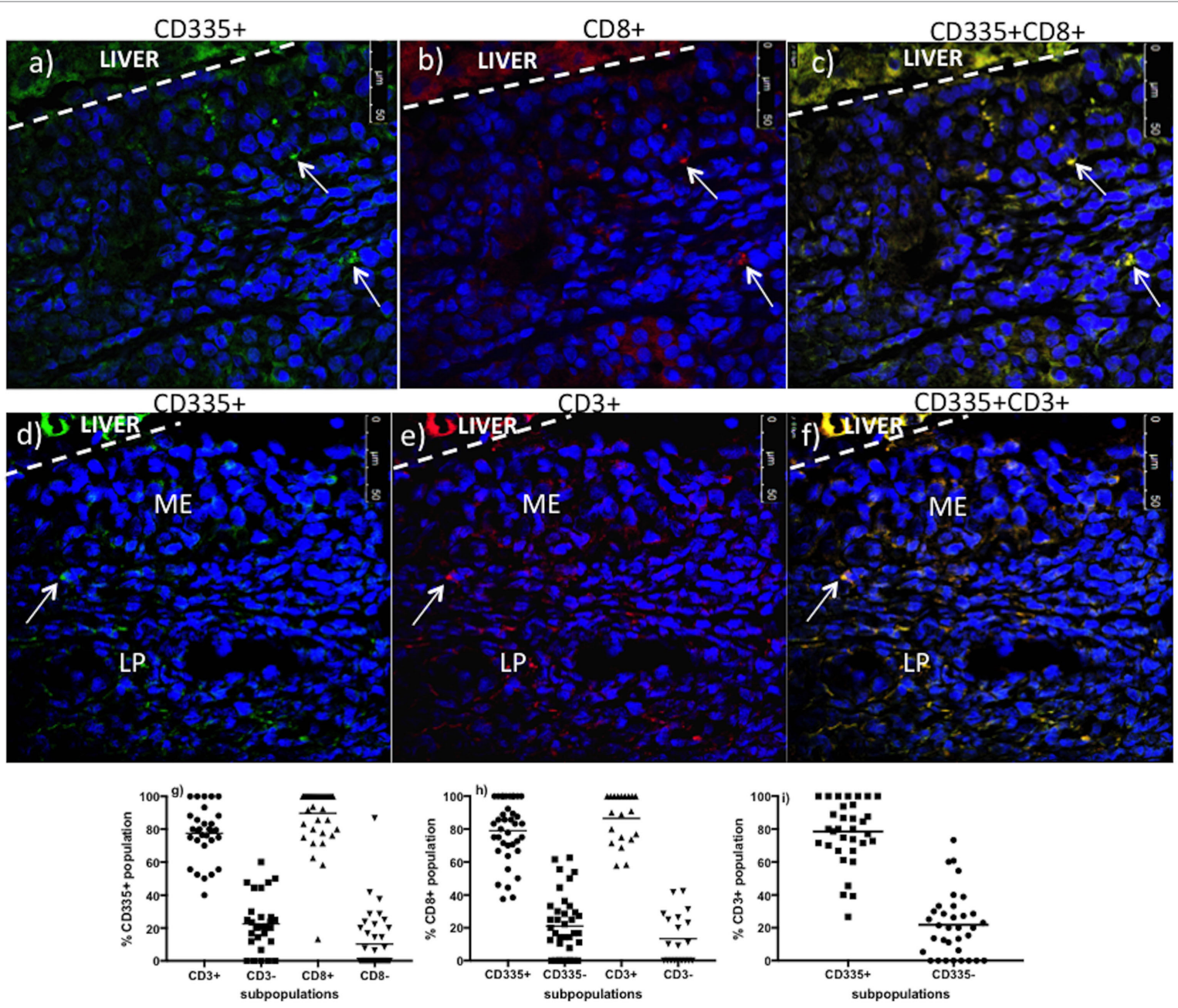

FIGURE 4 | Co-expression of CD3 and CD8 on CD335+cells present in nasal turbinates on day 5 after a primary bovine herpesvirus-1 (BHV-1) infection. Nasal turbinate tissue was collected on day 5 post-infection and mounted on a piece of liver to maintain the morphology of the mucosal epithelium. Tissues samples were cryopreserved and tissue sections double stained by immunofluorescence. Staining for CD335 [(A) - stained green] and CD8 [(B) - red] was super-imposed to identify CD335+CD8+ cells [(C) -yellow]. Staining for CD335 [(D) - stained green] and CD3 [(E) -red] was super-imposed to identify CD335 cells co-expressing CD3 [(F)-yellow]. The liver portion of the cryosections is indicated (LIVER) and a white dashed line demarcates the separation between liver and nasal turbinate. 4',6-diamidino-2-phenylindole was used as a counterstain to identify cell nuclei. Cell frequency data was generated through morphometric analyses. A minimum of $100 \mathrm{CD}_{3} 35^{+} \mathbf{( G )}, \mathrm{CD}^{+} \mathbf{( H )}$, and $\left.\mathrm{CD}^{+} \mathbf{(} \mathbf{(}\right)$ cells were counted per animal and tissue samples from three animals were used to analyze the frequency of $\mathrm{CD} 35^{+} \mathrm{CD} 3^{+}$, $\mathrm{CD}_{3} 35^{+} \mathrm{CD} 8^{+}$, and $\mathrm{CD}^{+}{ }^{+} \mathrm{CD} 8^{+}$cells. Each dot represents the \% cells of co-expressing the surface molecules indicated on the $y$-axis/per image/animal. ME, mucosal epithelium, LP, lamina propria. The images were captured at $63 \times$ magnification.

epithelium (4). When non-conventional T-cells are first recruited from blood, they may be abundant throughout the lamina propria but the apparent decline in lymphocyte number throughout the lamina propria on days 7 and 10 pi (Figure 2) may reflect further recruitment and localization of non-conventional T-cells to foci of viral infection. IHC studies analyzing lymphocyte subpopulations recruited specifically to foci of BHV-1 infection in the URT may better define the kinetics of effector lymphocyte populations recruited during viral infection.

Chemotactic migration of non-conventional T-cell subsets has been examined in mice and humans but the chemokines involved in non-conventional T-cell recruitment in cattle is not known. Murine iNKT cells express CCR7, CXCR3, CXCR6, CCR4, and CCR6 chemokine receptors (28), of which CCR4 was critical for localization to the lung (29). CXCR6, CCR1, and CCR6 are expressed on the surface of human NKT cells (30). These studies indicate that non-conventional T-cells express multiple chemokine receptors and individual receptors may be involved in tissue-specific recruitment. Bovine $\mathrm{CD} 335^{+} \mathrm{CD} 2^{+}$ NK cells have been shown to express several chemokine receptors including CCR1, CCR8, CXCR6, and CX3CR1, while CD $335^{+} \mathrm{CD} 2^{-} \mathrm{NK}$ cells expressed CCDR2, CCR5, CCR6, CCR7, CXCR3, CXCR4, and CXCR5 (45). Thus, bovine NK cells also have the capacity to respond to a broad range of chemokines. The expression of 11 known bovine chemokine genes was analyzed in nasal turbinate tissue collected following BHV-1 infection and CCL4, CCL5, CXCL9 were significantly $(P<0.05)$ upregulated (Figure 5). Transcript abundance for all three chemokine genes 

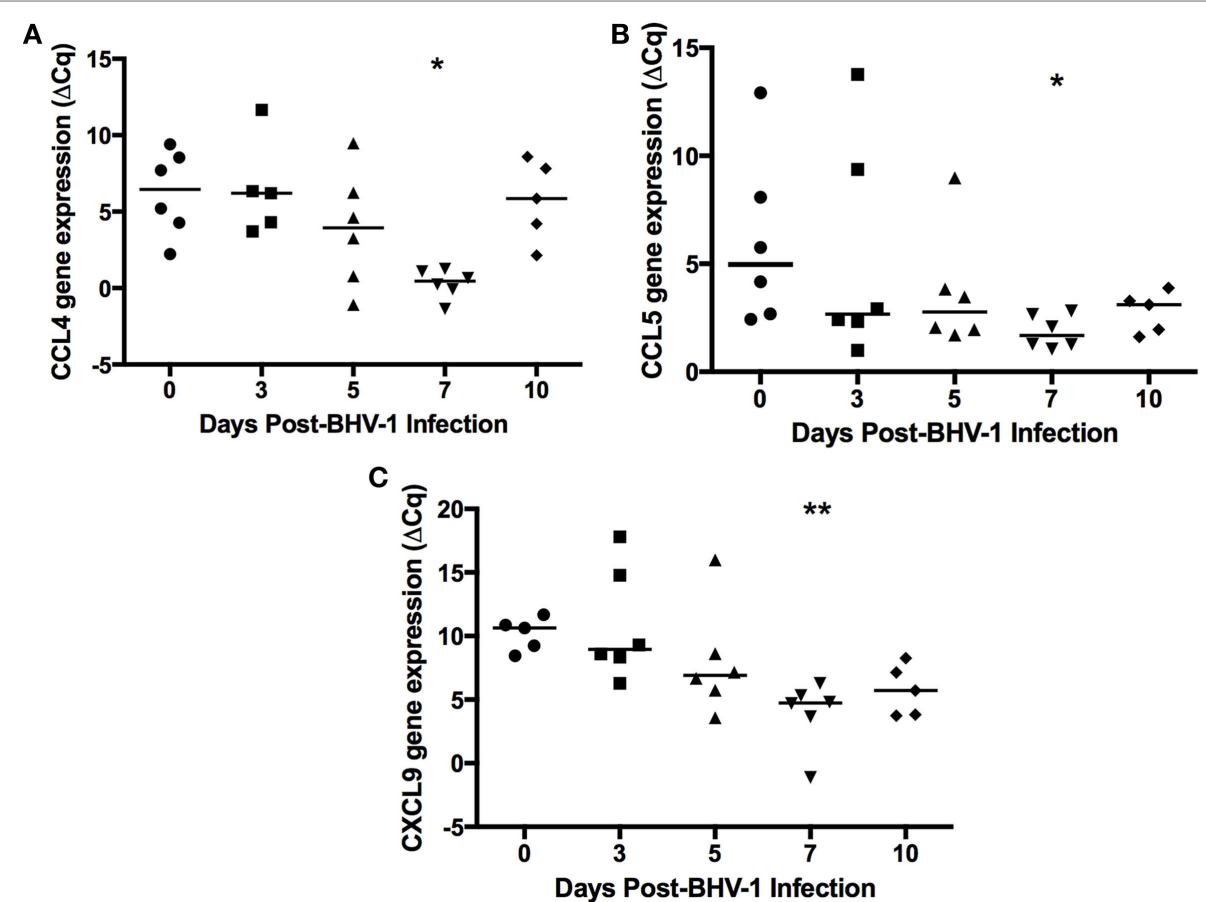

FIGURE 5 | Expression of chemokines in nasal turbinate tissue following primary bovine herpesvirus-1 (BHV-1) infection. Nasal turbinate samples were collected ( $n=6$ animals/time point) prior to and following BHV-1 infection and RNA extracted for qRT-PCR analysis abundance of CCL4 (A), CCL5 (B), CXCL9 (C) gene transcript abundance. Gene expression was calculated as the change in threshold cycle $(\Delta \mathrm{Cq})$ relative to $\beta$-actin and data presented are values for individual animals. The horizontal bar represents the mean value for animals sampled at each time sampled. A Mann-Whitney test was used to compare values relative to preinfection (day 0) levels. Significant changes in gene expression relative to day 0 are indicated: $P<0.0332\left(^{\star}\right), P \leq 0.0021\left(^{\star \star}\right)$.

was greatest on day 7 pi and then remained at a similar level on day 10 pi. Significant chemokine gene expression on day 7 pi coincided with the highest level of BHV-1 replication and shedding in nasal secretions (4). If these chemokines are involved in non-conventional T-cell recruitment to viral infected mucosal epithelial cells then the temporal pattern of chemokine gene expression may explain the apparent decline in the abundance of these T-cell subsets in the lamina propria on days 7 and 10 pi. It is also interesting that maximum CXCL9 gene expression occurred on day 7 pi, which is 2 days after peak IFN- $\gamma$ production in the URT (4). Increased expression of CXCL9, also known as monokine induced by IFN- $\gamma$ (MIG; Table 2), is consistent with the strong IFN- $\gamma$ response observed following BHV-1 infection (4). If CXCL9 is a chemokine involved in non-conventional T-cell recruitment then the IFN- $\gamma$ response induced during BHV-1 infection may play an indirect role in recruitment of this specific effector cell population. Further clarification of which chemokines are involved in the specific recruitment of non-conventional $\mathrm{T}$-cells will require an analysis of chemokine receptor expression on these cells.

\section{CONCLUSION}

The present study demonstrates that $\mathrm{CD} 335^{+} \mathrm{CD} 8^{+}$non-conventional T-cells are the predominant lymphocyte population recruited to the lamina propria of nasal turbinates within 5 days after a primary BHV-1 infection. Dual-color IF studies confirmed that over $75 \%$ of both $\mathrm{CD} 335^{+}$cells and $\mathrm{CD}^{+}$cells present in the lamina propria on day 5 pi could be classified as nonconventional T-cells. Although bovine $\mathrm{CD} 335^{+} \mathrm{CD} 8^{+}$cells are a minor lymphoid population in blood (12), over $30 \mathrm{CD} 335^{+} \mathrm{CD} 8^{+}$ T-cells $/ 0.196 \mathrm{~mm}^{2}$ were present in bovine nasal turbinate tissue on day 5 pi. This represents a highly specific recruitment of nonconventional T-cells and suggests that $\mathrm{CD} 335^{+} \mathrm{CD} 8^{+} \mathrm{T}$-cells may be an important effector population for the control or clearance of a herpesvirus infection. The recruitment of these non-conventional T-cells was associated with increased expression of three different chemokines, indicating that this tissue-specific recruitment may involve multiple chemoattractant signals. Finally, the T-cell receptor repertoire of these cells needs to be determined before classifying these cells as either innate or adaptive T-cells.

\section{ETHICS STATEMENT}

All experimental procedures were conducted according to the Guide to the Care and Use of Experimental Animals, provided by the Canadian Council on Animal Care and the experimental protocols were approved by the University of Saskatchewan Animal Care Committee (Protocol \#19940211 and 19940218).

\section{AUTHOR CONTRIBUTIONS}

PG and RO were responsible for conception, design of the study, and writing the manuscript. RO designed and validated 
primers, performed experiments, and analyzed data. PG assisted in data interpretation. All authors read and approved the final manuscript.

\section{ACKNOWLEDGMENTS}

This research was funded by the Saskatchewan Agriculture Development Fund (ADF; Ministry of Agriculture Saskatchewan) and the Natural Sciences and Engineering Research Council of Canada (NSERC). RO was supported by a Vaccinology and Immunotherapeutics Program, University of Saskatchewan Graduate Scholarship and Natural Sciences and Engineering Research Council: Collaborative Research and Training Experience (NSERC-CREATE) program, PG is funded by a Tier I Canada Research Chair (CRC) in Neonatal Mucosal

\section{REFERENCES}

1. Tikoo SK, Campos M, Babiuk LA. Bovine herpesvirus 1 (BHV-1): biology, pathogenesis, and control. Adv Virus Res (1995) 45:191-223. doi:10.1016/ s0065-3527(08)60061-5

2. Ackermann M, Peterhans E, Wyler R. DNA of bovine herpesvirus type 1 in the trigeminal ganglia of latently infected calves. Am J Vet Res (1982) 43(1):36-40.

3. Schuh JC, Bielefeldt Ohmann H, Babiuk LA, Doige CE. Bovine herpesvirus-1-induced pharyngeal tonsil lesions in neonatal and weanling calves. J Comp Pathol (1992) 106(3):243-53. doi:10.1016/0021-9975(92)90053-W

4. Osman R, Gonzalez-Cano P, Brownlie R, Griebel P. Induction of interferon and interferon-induced antiviral effector genes following a primary bovine herpes virus-1 (BHV-1) respiratory infection. J Gen Virol (2017) 98(7):1831-42. doi:10.1099/jgv.0.000825

5. Campos M, Rossi CR. In vitro induction of cytotoxic lymphocytes from infectious bovine rhinotracheitis virus hyperimmune cattle. Am J Vet Res (1986) 47(11):2411-4.

6. Splitter GA, Eskra L, Abruzzini AF. Cloned bovine cytolytic T cells recognize bovine herpes virus-1 in a genetically restricted, antigen-specific manner. Immunology (1988) 63(1):145-50.

7. Campos M, Griebel P, Bielefeldt Ohmann H, Babiuk LA. Cell-mediated cytotoxic responses in lungs following a primary bovine herpes virus type 1 infection. Immunology (1992) 75(1):47-52.

8. Lanier LL. NK cell recognition. Annu Rev Immunol (2005) 23:225-74. doi:10.1146/annurev.immunol.23.021704.115526

9. Storset AK, Kulberg S, Berg I, Boysen P, Hope JC, Dissen E. NKp46 defines a subset of bovine leukocytes with natural killer cell characteristics. Eur J Immunol (2004) 34(3):669-76. doi:10.1002/eji.200324504

10. Achdout H, Meningher T, Hirsh S, Glasner A, Bar-On Y, Gur C, et al. Killing of avian and swine influenza virus by natural killer cells. J Virol (2010) 84(8):3993-4001. doi:10.1128/JVI.02289-09

11. Bryceson YT, March ME, Ljunggren HG, EO L. Activation, co-activation, and co-stimulation of resting human NK cells. Immunol Rev (2006) 214:73-91. doi:10.1111/j.1600-065X.2006.00457.x

12. Connelley TK, Longhi C, Burrells A, Degnan K, Hope J, Allan AJ, et al. NKp46+ CD3+ cells: a novel nonconventional T cell subset in cattle exhibiting both NK cell and T cell features. J Immunol (2014) 192(8):3868-80. doi:10.4049/ jimmunol.1302464

13. Mair KH, Stadler M, Talker SC, Forberg H, Storset AK, Müllebner A, et al. Porcine CD3(+)NKp46(+) lymphocytes have NK-cell characteristics and are present in increased frequencies in the lungs of influenza-infected animals. Front Immunol (2016) 7:263. doi:10.3389/fimmu.2016.00263

14. Olsen L, Akesson CP, Storset AK, Lacroix-Lamande S, Boysen P, Metton C, et al. The early intestinal immune response in experimental neonatal ovine cryptosporidiosis is characterized by an increased frequency of perforin expressing NCR1(+) NK cells and by NCR1(-) CD8(+) cell recruitment. Vet Res (2015) 46:28. doi:10.1186/s13567-014-0136-1
Immunology provided by Canada Institutes for Health Research (CIHR). We would like to thank Nathalie Berube and Dr. Patricia Gonzalez-Cano for their technical assistance with confocal imaging and primer design and validation, respectively. We also acknowledge the excellent technical assistance provided by Dr. Don Wilson, Brock Evans, and the staff of Prairie Diagnostics Services, Saskatoon, SK, Canada when collecting samples from animals. This manuscript is published with permission of the Director of VIDO-Intervac as journal series \# 814.

\section{SUPPLEMENTARY MATERIAL}

The Supplementary Material for this article can be found online at http://www.frontiersin.org/article/10.3389/fimmu.2017.01393/ full\#supplementary-material.

15. Meresse B, Curran SA, Ciszewski C, Orbelyan G, Setty M, Bhagat G, et al. Reprogramming of CTLs into natural killer-like cells in celiac disease. J Exp Med (2006) 203(5):1343-55. doi:10.1084/jem.20060028

16. Walzer T, Blery M, Chaix J, Fuseri N, Chasson L, Robbins SH, et al. Identification, activation, and selective in vivo ablation of mouse NK cells via NKp46. Proc Natl Acad Sci U S A (2007) 104(9):3384-9. doi:10.1073/ pnas.0609692104

17. Fowlkes BJ, Kruisbeek AM, Ton-That H, Weston MA, Coligan JE, Schwartz RH, et al. A novel population of T-cell receptor alpha beta-bearing thymocytes which predominantly expresses a single $\mathrm{V}$ beta gene family. Nature (1987) 329(6136):251-4. doi:10.1038/329251a0

18. Makino Y, Kanno R, Ito T, Higashino K, Taniguchi M. Predominant expression of invariant $\mathrm{V}$ alpha $14+\mathrm{TCR}$ alpha chain in NK1.1+ T cell populations. Int Immunol (1995) 7(7):1157-61. doi:10.1093/intimm/7.7.1157

19. Godfrey DI, MacDonald HR, Kronenberg M, Smyth MJ, Van Kaer L. NKT cells: what's in a name? Nat Rev Immunol (2004) 4(3):231-7. doi:10.1038/ nri1309

20. Thomas SY, Hou R, Boyson JE, Means TK, Hess C, Olson DP, et al. CD1drestricted NKT cells express a chemokine receptor profile indicative of Th1-type inflammatory homing cells. J Immunol (2003) 171(5):2571-80. doi:10.4049/jimmunol.171.5.2571

21. Van Rhijn I, Koets AP, Im JS, Piebes D, Reddington F, Besra GS, et al. The bovine CD1 family contains group $1 \mathrm{CD} 1$ proteins, but no functional CD1d. J Immunol (2006) 176(8):4888-93. doi:10.4049/jimmunol.176.8.4888

22. Pirson C, Engel R, Jones GJ, Holder T, Holst O, Vordermeier HM. Highly purified mycobacterial phosphatidylinositol mannosides drive cell-mediated responses and activate NKT cells in cattle. Clin Vaccine Immunol (2015) 22(2):178-84. doi:10.1128/cvi.00638-14

23. Porcelli S, Yockey CE, Brenner MB, Balk SP. Analysis of T cell antigen receptor (TCR) expression by human peripheral blood CD4-8- alpha/beta T cells demonstrates preferential use of several $\mathrm{V}$ beta genes and an invariant TCR alpha chain. J Exp Med (1993) 178(1):1-16. doi:10.1084/jem.178.1.1

24. Treiner E, Duban L, Bahram S, Radosavljevic M, Wanner V, Tilloy F, et al. Selection of evolutionarily conserved mucosal-associated invariant $\mathrm{T}$ cells by MR1. Nature (2003) 422(6928):164-9. doi:10.1038/nature01433

25. Napier RJ, Adams EJ, Gold MC, Lewinsohn DM. The role of mucosal associated invariant T cells in antimicrobial immunity. Front Immunol (2015) 6:344. doi:10.3389/fimmu.2015.00344

26. Kjer-Nielsen L, Patel O, Corbett AJ, Le Nours J, Meehan B, Liu L, et al. MR1 presents microbial vitamin B metabolites to MAIT cells. Nature (2012) 491(7426):717-23. doi:10.1038/nature11605

27. Gregoire C, Chasson L, Luci C, Tomasello E, Geissmann F, Vivier E, et al. The trafficking of natural killer cells. Immunol Rev (2007) 220:169-82. doi:10.1111/j.1600-065X.2007.00563.x

28. Watarai H, Sekine-Kondo E, Shigeura T, Motomura Y, Yasuda T, Satoh R, et al. Development and function of invariant natural killer $\mathrm{T}$ cells producing T(H)2- and T(H)17-cytokines. PLoS Biol (2012) 10(2):e1001255. doi:10.1371/ journal.pbio. 1001255 
29. Meyer EH, Wurbel MA, Staton TL, Pichavant M, Kan MJ, Savage PB, et al. iNKT cells require CCR4 to localize to the airways and to induce airway hyperreactivity. J Immunol (2007) 179(7):4661-71. doi:10.4049/ jimmunol.179.7.4661

30. Lee LN, Ronan EO, de Lara C, Franken KLMC, Ottenhoff THM, Tchilian EZ, et al. CXCR6 is a marker for protective antigen-specific cells in the lungs after intranasal immunization against Mycobacterium tuberculosis. Infect Immun (2011) 79(8):3328-37. doi:10.1128/IAI.01133-10

31. Braun R, Babiuk LA, van Drunen Littel-van den Hurk S. Compatibility of plasmids expressing different antigens in a single DNA vaccine formulation. JGen Virol (1998) 79(12):2965-70. doi:10.1099/0022-1317-7912-2965

32. Hodgson PD, Aich P, Stookey J, Popowych Y, Potter A, Babiuk L, et al. Stress significantly increases mortality following a secondary bacterial respiratory infection. Vet Res (2012) 43:21. doi:10.1186/1297-9716-43-21

33. Griebel PJ, Kennedy L, Graham T, Davis WC, Reynolds JD. Characterization of B-cell phenotypic changes during ileal and jejunal Peyer's patch development in sheep. Immunology (1992) 77:564-70.

34. Mirabzadeh-Ardakani A, Solie J, Gonzalez-Cano P, Schmutz SM, Griebel PJ. Tissue- and age-dependent expression of the bovine DEFB103 gene and protein. Cell Tissue Res (2016) 363(2):479-90. doi:10.1007/s00441-0152258-9

35. Gonzalez-Cano P, Arsic N, Popowych YI, Griebel PJ. Two functionally distinct myeloid dendritic cell subpopulations are present in bovine blood. Dev Comp Immunol (2014) 44(2):378-88. doi:10.1016/j.dci.2014.01.014

36. Fries P, Popowych YI, Guan LL, Beskorwayne T, Potter A, Babiuk L, et al. Mucosal dendritic cell subpopulations in the small intestine of newborn calves. Dev Comp Immunol (2011) 35(10):1040-51. doi:10.1016/j.dci.2011. 04.003

37. Waters WR, Harp JA, Nonnecke BJ. Phenotypic analysis of peripheral blood lymphocytes and intestinal intra-epithelial lymphocytes in calves. Vet Immunol Immunopathol (1995) 48:249-59. doi:10.1016/0165-2427(95)05430-E

38. Wehr A, Baeck C, Heymann F, Niemietz PM, Hammerich L, Martin C, et al. Chemokine receptor CXCR6-dependent hepatic NK T cell accumulation promotes inflammation and liver fibrosis. J Immunol (2013) 190(10):5226-36. doi:10.4049/jimmunol.1202909
39. Tomasello E, Yessaad N, Gregoire E, Hudspeth K, Luci C, Mavilio D, et al. Mapping of NKp46(+) cells in healthy human lymphoid and non-lymphoid tissues. Front Immunol (2012) 3:344. doi:10.3389/fimmu.2012.00344

40. Graham EM, Thom ML, Howard CJ, Boysen P, Storset AK, Sopp P, et al. Natural killer cell number and phenotype in bovine peripheral blood is influenced by age. Vet Immunol Immunopathol (2009) 132(2-4):101-8. doi:10.1016/j. vetimm.2009.05.002

41. Todd JD. Immune response to infectious bovine rhinotracheitis virus (IBRV) following natural infection or vaccination by intranasally or parenterally administered vaccines. Dev Biol Stand (1975) 28:526-9.

42. Raggo C, Habermehl M, Babiuk LA, Griebel P. The in vivo effects of recombinant bovine herpesvirus-1 expressing bovine interferon-gamma. J Gen Virol (2000) 81(Pt 11):2665-73. doi:10.1099/0022-1317-81-11-2665

43. Huang Y, Babiuk LA, van Drunen Littel-van den Hurk S. Immunization with a bovine herpesvirus 1 glycoprotein B DNA vaccine induces cytotoxic T-lymphocyte responses in mice and cattle. J Gen Virol (2005) 86(Pt 4):887-98. doi:10.1099/vir.0.80533-0

44. Pak-Wittel MA, Yang L, Sojka DK, Rivenbark JG, Yokoyama WM. Interferongamma mediates chemokine-dependent recruitment of natural killer cells during viral infection. Proc Natl Acad Sci U S A (2013) 110(1):E50-9. doi:10.1073/pnas.1220456110

45. Siddiqui N, Hope J. Differential recruitment and activation of natural killer cell sub-populations by Mycobacterium bovis-infected dendritic cells. Eur J Immunol (2013) 43(1):159-69. doi:10.1002/eji.201242736

Conflict of Interest Statement: The authors declare that the research was conducted in the absence of any commercial or financial relationships that could be construed as a potential conflict of interest.

The reviewer $\mathrm{JH}$ and handling editor declared their shared affiliation.

Copyright (C) 2017 Osman and Griebel. This is an open-access article distributed under the terms of the Creative Commons Attribution License (CC BY). The use, distribution or reproduction in other forums is permitted, provided the original author(s) or licensor are credited and that the original publication in this journal is cited, in accordance with accepted academic practice. No use, distribution or reproduction is permitted which does not comply with these terms. 